\title{
Distrust of the State and observance of the law among peasants in the San Nicolas Valley
}

\author{
Desconfiança do Estado e observância da lei nos fazendeiros do Vale do São \\ Nicolau
}

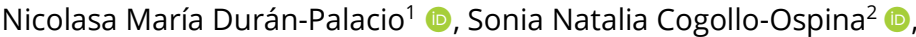 \\ Norman Darío Moreno-Carmona ${ }^{3}$ [D \\ ${ }^{1}$ Universidad Católica Luis Amigó, Medellín, Antioquia, Colombia. E-mail: nicolasa.duranpa@amigo.edu.co \\ 2Universidad de Antioquia, Medellín, Antioquia, Colombia. E-mail: sonia.cogollo@udea.edu.co \\ ${ }^{3}$ Universidad de San Buenaventura, Medellín, Antioquia, Colombia. E-mail: nordamo@hotmail.com
}

\begin{abstract}
How to cite: Durán-Palacio, N. M, Cogollo-Ospina, S. N., \& Moreno-Carmona, N. D. (2021). Distrust of the State and observance of the law among peasants in the San Nicolas Valley. Revista de Economia e Sociologia Rural, 59(1), e216031. https://doi.org/10.1590/1806-9479.2021.216031
\end{abstract}

\begin{abstract}
In Colombia, political decisions related to the countryside preserve an unjust social order, maintaining inequities and obstacles to the well-being and life quality of farmers. In this scenario the Territorial Arrangement Planning of the San Nicolas Valley, in the East of the department of Antioquia, has generated a series of rural conflicts that accentuate the vulnerabilities of rural residents, threatening the agricultural tradition in this subregion. Thus, this study inquired about the perceptions of legality in the peasant population of the area. A descriptive-correlational study with non-probabilistic sampling was carried out, including 380 peasants, members of civic-rural associations of the San Nicolas Valley, evaluating in four scales: beliefs, values, knowledge of the law and perceived legality in the context. Statistical analyses were performed in SPSS v.22 software. The findings indicated significant relationships between the study variables. Despite the state abandonment of the proletariat to market forces in an area with socioeconomic imbalances, no determining link was found between low income and violation of the law.
\end{abstract}

Keywords: perception, social justice, peasants, beliefs, social values.

Resumo: Na Colômbia, as decisões políticas relacionadas ao campo preservam uma ordem social injusta, mantêm as desigualdades e os obstáculos ao bem-estar e à qualidade de vida dos agricultores. É assim que o Plano de Ordenamento Territorial do Vale de San Nicolás, no leste do departamento de Antioquia, gerou uma série de conflitos rurais que acentuam as vulnerabilidades dos moradores rurais, ameaçando a tradição agrícola nessa sub-região. Diante dessa situação, este estudo indagou sobre as percepções de legalidade na população camponesa da área, por meio de um estudo descritivo-correlacional, com amostragem não probabilística, que incluiu 380 camponeses, membros de associações cívico-rurais do Vale de San Nicolás, avaliando quatro escalas, crenças, valores, conhecimento da lei e legalidade, percebidas no contexto. As análises estatísticas foram realizadas no SPSS v. 22. Os resultados indicam relações significativas entre as variáveis do estudo. Apesar do abandono estatal do proletariado às forças de mercado em uma área com desequilíbrios socioeconômicos, nenhuma ligação determinante foi encontrada entre baixa renda e violação da lei.

Palavras-chave: percepção, justiça social, camponeses, crenças, valores sociais.

\section{Introduction}

The progressive territorial and socio-spatial reconfiguration of the San Nicolas Valley -also known as the Altiplano of the Antioquia East or the Near East - has given rise to a series of social, ecological, economic and political-changing dynamics, not without tensions and conflicts between the different actors of the civil society and capital groups with political-private 
interests. The conflicts of interest are reflected in the visions of progress proposed by the public institutions in their development plans and the formulations of territorial ordering.

In the eighties, there were significant changes in the occupation of the territory (Plan Estratégico del Oriente Antioqueño, 2009). The expansion of areas for industry, residential and recreational subdivisions for new wealthy residents from Medellín and other cities have increased their cost and the consequent increases in both property taxes and public services domiciliary, also transforming the land use (García, 2007; Piedrahita Yepes, 2013; Programa de las Naciones Unidas para el Desarrollo, 2010; Restrepo Ramírez, 2015; Sierra, 2015). As a consequence, and due to their low purchasing power, the farmworkers have had to modify their way of life and links with the habitat. They had to sell their land, migrate to other territories or become overseers of the property that was their before.

The asymmetry of powers in the area and the progressive weakening of the capacities of local governments, concerning the higher levels of departmental and national political decision, contribute decisively to the loss of the capability for self-management, regulation of powers and citizen oversight related to the development of public affairs (Restrepo Ramírez, 2015), which actions that can only be carried out by organized communities (Plan Estratégico del Oriente Antioqueño, 2009). On the other hand, the reactions of the civil associations, through democratic means in the San Nicolas Valley, have not been enough to resist the degrading and slow the advance of the industry and the services of the political-private alliances on the rural territories (Restrepo Ramírez, 2015).

The establishment of new inhabitants and activities in the area not only promotes the emergence of socio-spatial conflicts that reconfigure rurality but also the alteration of cultural patterns, identity, way of life, customs, and worldviews typical of the rural peasant population. Likewise, the high population density (65\%) and the high concentration index of economic activity (92\%) that the Near East possesses (Plan Estratégico del Oriente Antioqueño, 2009), favor the appearance of problems related to food sovereignty, coexistence, citizen security and illegality.

Some consequences of the armed conflict persist in the territory, specifically the destruction of traditional ethical values and the insufficient recovery of lost social capital, which means an attitude favorable to authoritarianism, social exclusion, increase of crime in urban and rural locations (Plan Estratégico del Oriente Antioqueño, 2009). For its inhabitants, the problems of security and coexistence have increased. Street robberies, the sale, and micro-trafficking of illegal substances are perceived as the most significant threats (Antioquia, 2014).

\section{Theoretical foundation}

Most of the studies related to the perception of legality in citizens deal with illegality, legitimacy, corruption, authoritarianism, perception of citizen security, victimization, violence, crimes (Duque, 2013; Montoya \& Pizzolitto, 2015), and culture of legality (Godson, 2000; Cortés Guardado, 2006; Salazar Ugarte, 2006; Wences et al., 2014). These investigations were carried out mainly in urban contexts and not in rural farmworker settlers.

Regarding the authoritarianism and its facilitating attitudes, the investigation by Tyler et al. (2012) suggests that people's orientations concerning the potential use of violence are directly related to the evaluation of police effectiveness. When people believe that the police are effective in fighting crime, they consider violence by their own hands unnecessary and tend not to justify it. Likewise, the fear of being a victim of crime is directly related to attitudes favoring self-defense, property protection and political violence. According to Black's (1983) work, crime is a social control, that shows the interaction between the absence of the State and the distribution of violence. The normative attitudes of people related to the State predict their attitudes to private abuse. Similarly, the uneven distribution of violence and social control correlates with the availability of legal resources and unresolved social complaints.

The Spanish study on the culture of legality (Morán, 2014) indicates a problematic relationship between legal culture and social inequalities. Subjects with a lower level of schooling support the social order imposed by the State, even if it implies a limitation of citizens' rights and freedoms, at the same time that they present a more concise perception of the obstacles to the exercise of their rights. Meanwhile, people with high school, technical 
and university levels perceive more inequalities and consider that the distribution of income is unfair. The lower-middle class and working-class recognize more significant imbalances before the law, attribute low impartiality to its application, and a lower perception of its compliance. However, they consent less to the violation of legal norms (Morán, 2014).

The investigations not only highlight differences between social classes and levels of schooling in the evaluation that people make of the effectiveness of the State in controlling violence and crime, but also attitudes related to legality. The contrasts between age groups are also relevant when considering the subjects' appreciation of authority and equality in the application of the law. In this regard, the study by Alvarado Mendoza (2015) on the perceptions of justice, legality and legitimacy of young people in ten Latin American cities, found that the vision of the behavior of the authorities and representatives of the public and judicial power influences the assessment, acceptance and obedience to the norm in this population. Young people criticize the arbitrary exercise of authority in the application of the law; they perceive as unfair and inequitable the justice system of their countries, considering it favorable to political elites and wealthy families. This aspect leads them to observe a great distance between formally written law and its compliance. In turn, they abstain from participating in political activities and show little knowledge of their rights.

On the other hand, in the geographic context closest to this research, specifically in the capital of Antioquia, linked to the relationship between attitudes concerning legality and a feeling of security, the Perception Survey on Security, Victimization and Coexistence in Medellin shows that the two public institutions that people are most familiar with are the Police and the National Army (Medellín, 2015). Both manage security issues through control, while the least known are the Ministry of Security and Coexistence, the Conciliation Centers, and the Equity Conciliator focused on the management of coexistence matters. Likewise, the results highlights that the citizens of Medellin are highly distrustful of the others, but they trust the family prominently. As for public institutions, people from Medellin have a higher level of trust in the National Army, in the Catholic Church and little or no confidence in Congress and in the President of the Republic. Some significant correlations are highlighted in the present study: The younger the age, the schooling and the income, the higher tendency to have confidence in others, while the older and with better security conditions, the more confidence in the National Army. Regarding the attitude on the law, 30\% of the participants considered that disobedience to the rules is a custom, $20 \%$ believe that it is the only way to fight against an unjust law or regime publicly, and $16 \%$ think that disobeying it is the only way to help the family.

Therefore, the issue of legality perceived and lived by citizens requires the most considerable investigative interest, since some studies have found that the naturalization of illegality or the increase in its perception, make it impossible to materialize justice and, even, place this question at the center of the problems of some Latin American societies in crisis (Moriconi Bezerra, 2015).

With the political promises of a new agrarian order and agricultural production in Colombia, it is necessary to foster a culture of legality and promote relationships of greater trust and solidarity among the various inhabitants. In reality, empirical studies on perceived legitimacy in rural contexts are scarce. Faced with this gap, the objective of this work was to investigate the perceptions of legality in the peasants of the San Nicolas Valley.

\section{Methodology}

\section{Participants}

The sample was non-probability, composed of 380 peasants members of civic-rural associations from the nine municipalities from San Nicolas Valley, which $44.7 \%$ of them were men and $55.3 \%$ women, with an average age of 49.12 years $(S D=15.55)$, with incomplete primary or secondary education, with a relationship (married or in a consensual union) and the majority are parents. The professed religion was Catholic. They belong to the three lowest socioeconomic classes (72.7\% in stratum 1 and 2 ), and most of them live in owner-occupied or family homes. (Table 1) 
Table 1. Demographic characteristics of the participants. $(N=380)$

\begin{tabular}{|c|c|c|}
\hline Characteristic & $\mathbf{n}$ & $\%$ \\
\hline \multicolumn{3}{|l|}{ Municipality } \\
\hline El Carmen de Viboral & 56 & 14.7 \\
\hline El Retiro & 16 & 4.2 \\
\hline Guarne & 23 & 6.1 \\
\hline La Ceja & 79 & 20.8 \\
\hline La Unión & 39 & 10.3 \\
\hline Marinilla & 45 & 11.8 \\
\hline Rionegro & 67 & 17.6 \\
\hline Santuario & 38 & 10.0 \\
\hline San Vicente & 17 & 4.5 \\
\hline \multicolumn{3}{|l|}{ Gender } \\
\hline Men & 170 & 44.7 \\
\hline Women & 210 & 55.3 \\
\hline \multicolumn{3}{|l|}{ Age } \\
\hline-31 & 59 & 15.5 \\
\hline $31-45$ & 89 & 23.4 \\
\hline $46-60$ & 147 & 38.7 \\
\hline+60 & 85 & 22.4 \\
\hline \multicolumn{3}{|l|}{ Occupation } \\
\hline Farmworker & 119 & 31.3 \\
\hline Rancher & 8 & 2.1 \\
\hline Housewife & 173 & 45.5 \\
\hline Employee & 61 & 16.1 \\
\hline Unemployed & 19 & 5.0 \\
\hline \multicolumn{3}{|l|}{ Schooling } \\
\hline No studies & 11 & 2.9 \\
\hline Incomplete Elementary Education & 127 & 33.4 \\
\hline Elementary education & 92 & 24.2 \\
\hline Middle School & 54 & 14.2 \\
\hline High School & 75 & 19.7 \\
\hline University studies & 21 & 5.5 \\
\hline \multicolumn{3}{|l|}{ Socioeconomic stratum } \\
\hline 1. Lowest social stratum & 47 & 12.4 \\
\hline 2. Low income & 229 & 60.3 \\
\hline 3. Low-middle income & 104 & 27.4 \\
\hline \multicolumn{3}{|l|}{ Maritial Status } \\
\hline Single & 55 & 14.5 \\
\hline Married & 216 & 56.8 \\
\hline Consensual union & 45 & 11.8 \\
\hline Divorced & 4 & 1.1 \\
\hline Separated & 22 & 5.8 \\
\hline Widow / widower & 38 & 10.0 \\
\hline \multicolumn{3}{|l|}{ Children? } \\
\hline Yes & 328 & 86.3 \\
\hline No & 52 & 13.7 \\
\hline \multicolumn{3}{|l|}{ Type of property } \\
\hline Own & 198 & 52.1 \\
\hline Family & 83 & 21.8 \\
\hline Rented & 71 & 18.7 \\
\hline Commodatum & 28 & 7.4 \\
\hline Squatter & 0 & 0.0 \\
\hline \multicolumn{3}{|l|}{ Religion } \\
\hline Catholic & 363 & 95.5 \\
\hline Christian & 6 & 1.6 \\
\hline Protestant & 0 & 0.0 \\
\hline Non-Believer & 5 & 1.3 \\
\hline Other & 6 & 1.6 \\
\hline
\end{tabular}

Source: Own development 


\section{Instruments}

Four scales were developed: (1) beliefs; (2) values; (3) knowledge; and (4) context perception. Concepts concerning the legality, legitimacy and instruments used in previous studies such as the culture of legality in Latin American countries (Cortés Guardado, 2006; Wences et al., 2014), citizen culture (Corpovisionarios, 2015) and controversial moral behaviors (Mathiesen et al., 1998) were also included.

The design of the knowledge scales of the law and access to justice through state entities was carried out with the option of a dichotomous response; the other scales were performed by Likert type with four response options. In the case of values and context perception, they range from 1 = Never to 4 = Always, and the belief scale ranges from $1=$ completely disagree to 4 = completely agree.

The instrument was piloted by a sample of 86 adults from the region: 37 men and 49 women, aged between 19 and 79 years. The average age was 42.67 with a standard deviation of 14.76. The scale of knowledge and difficulty index were calculated; all the items showed adequate difficulty, even showing a tendency for being easy, and all showed good discrimination ( $p \leq .05)$.

The factorial validity of the beliefs scales, values and context perception was reviewed by a principal component analysis with varimax rotation (Hair et al., 1999), and the reliability was calculated using the coefficients of internal consistency (Cronbach's alpha). The factor analysis was exploratory and in the final version, a second-order factor was used to make a more parsimonious model.

For the scales of beliefs, values and context perception, it was observed that the internal consistency of the scales was adequate, obtained by Cronbach's alpha. (Table 2)

Table 2. Reliability scales and factors of legality perception

\begin{tabular}{cccc}
\multirow{2}{*}{$\begin{array}{c}\text { Scale } \\
\text { Beliefs }\end{array}$} & Factor/dimension (\# reactive) & \multicolumn{2}{c}{ Cronbach's Alpha } \\
\cline { 3 - 4 } & Cannot trust the State and justify disobeying the law (12) & 0.82 & 0.7 \\
& Justify deceiving the State and the use of violence (16) & & Factor \\
Values & Altruism / Prosociality (5) & 0.64 & 0.62 \\
& Respect for differences (4) & 0.78 \\
Context & Violence and disrespect for rules and neighbors (12) & 0.79 & 0.7 \\
perception & Mistrust in the State (9) & & 0.8 \\
& Insecurity and mistrust in the sector (5) & & 0.54 \\
\hline
\end{tabular}

Source: Own development.

Construct validity was explored by a set of correlation coefficients calculated between the factor scores and all presented statistically significant correlations within each scale. The two belief factors obtained $R=.503(p \leq .001)$, the two value factors $R=.389(p \leq .001)$ and the three context perception factors presented the correlations observed in Table 3. Statistical analyzes were performed in SPSS v.22.

Table 3. Association analysis between the factors of the Context Perception Scale

\begin{tabular}{lcccc} 
& $\mathbf{M}$ & $\mathbf{D E}$ & $\mathbf{2}$ & $\mathbf{3}$ \\
1. Violence and disrespect for rules and neighbors & 1.63 & .38 & $.365^{* * *}$ & $.129^{*}$ \\
2. Mistrust in the State & 2.57 & .51 & $.119^{*}$ \\
3. Insecurity and mistrust in the sector & 2.31 & .47 & & \\
\hline
\end{tabular}

Source: Own development. 
Process

Access to the population was facilitated through peasant organizations in the subregion. The objective of the research was explained to the participants, their voluntary participation was requested and the signature of their informed consent was obtained. The instruments were self-applicable and in illiteracy cases, the questions were read to the person. Anonymity was ensured.

Results

The scales of beliefs, values and perceptions of context are Likert type, ranging from 1 to 4 with a theoretical average of 2.5. It is necessary to clarify that the scale of beliefs is presented in negative terms (justifying the use of violence, deceiving the State, disobeying the law). Table 4 indicates that the mean of said component scores is low, showing that in the rural population, there is a low tendency to consider negative beliefs about legality; mainly, they do not consider disobeying the law based on the low confidence of the State $(M=1.87)$.

Table 4. Average, standard deviations and correlations between the attitude scales and the perception of legality

\begin{tabular}{|c|c|c|c|c|c|}
\hline \multicolumn{6}{|l|}{ Measure } \\
\hline Attitude and perception & $\mathbf{M}$ & DE & Values & Knowledge & $\begin{array}{c}\text { Context } \\
\text { perception }\end{array}$ \\
\hline Beliefs & 2.15 & .35 & -.069 & $.104 *$ & $.158 * \star$ \\
\hline Values & 3.47 & .38 & & $.193 * \star$ & $-.218 * \star \star$ \\
\hline Knowledge & 11.76 & 2.76 & & & .037 \\
\hline Context perception & 2.13 & .34 & & & \\
\hline
\end{tabular}

Source: Own development.

The same could be seen in the context perception, since the scale also evaluates a negative estimate, indicating that the rural population tends to have a positive appreciation of its context in terms of legality (Table 4), especially concerning the violence in the sector and respect for norms and neighbors $(\mathrm{M}=1.63)$; The perception of low trust in the State contributes negatively to this scale $(M=2.57)$.

The average in the scale of the law knowledge shows in this study that, in general, the peasant population knows the law, with an average of 11.76 correct answers on 17 questions.

The average of the scale of values indicates that prosociality/altruism and respect for differences are very present values in the peasants and that these correlate negatively with the perception of the context and positively with the beliefs; presenting higher scores in values, lower scores in negative beliefs and less negative perception of the context.

The results highlights that in the sample, the values correlate with knowledge, but not with beliefs. While the context perception correlates with beliefs, but not with knowledge.

When comparing the scores between men and women, the T-test data indicated that there are no statistically significant differences between the genders in any of the scales (Table 5). However, analytically certain factors establish some differences: Women are more altruistic and prosocial $(M=3.78)$ than men $(M=3.69)$, while men perceive more insecurity and mistrust in the sector $(\mathrm{M}=2.38)$ than women $(\mathrm{M}=2.25)$. 
Table 5. Average, Standard Deviations and T-test of independent samples for Scales and Perception Factors of Legality according to gender

\begin{tabular}{|c|c|c|c|c|c|}
\hline \multirow{2}{*}{ Scale } & \multicolumn{2}{|c|}{ Men } & \multicolumn{2}{|c|}{ Women } & \multirow{2}{*}{$\mathbf{t}$} \\
\hline & M & DE & M & DE & \\
\hline BELIEFS & 2.18 & .35 & 2.12 & .35 & 1.791 \\
\hline $\begin{array}{l}\text { Cannot trust the State and justify disobeying the } \\
\text { law }\end{array}$ & 1.91 & .35 & 1.84 & .32 & 1.961 \\
\hline Justify deceiving the State and the use of violence & 2.56 & .46 & 2.49 & .50 & 1.480 \\
\hline VALUES & 3.46 & .39 & 3.48 & .38 & -.459 \\
\hline Altruism / Prosociality & 3.69 & .37 & 3.78 & .32 & $-2.639 * *$ \\
\hline Respect for differences & 3.18 & .57 & 3.10 & .62 & 1.257 \\
\hline KNOWLEDGE & 11.64 & 2.70 & 11.85 & 2.80 & -.742 \\
\hline CONTEXT PERCEPTION & 2.13 & .33 & 2.12 & .35 & .275 \\
\hline Violence and disrespect for rules and neighbors & 1.62 & .37 & 1.64 & .39 & -.335 \\
\hline Mistrust in the State & 2.57 & .49 & 2.57 & .53 & .017 \\
\hline Insecurity and mistrust in the sector & 2.38 & .45 & 2.25 & .49 & $2.606 * \star$ \\
\hline
\end{tabular}

Source: Own development.

In the age variable, according to Table 6, there are significant differences in the scales of values and perception of the context, highlighting that the youngest population (under 31 years-old) presents a less tendency to altruism and respect for differences than those older. Likewise, they have a more negative perception of the context than the elderly, while they perceive more violence in the sector, lack of respect for norms and neighbors and less trust in the State. It is worth reminding that the scores on values in the sample are quite high overall. Although young people have obtained a lower score, this does not lead to the conclusion that they do not possess these values.

Table 6. Average, standard deviations and Anova of a factor for scales and factors of legality perception by age groups

\begin{tabular}{|c|c|c|c|c|c|c|c|c|c|c|}
\hline \multirow[t]{2}{*}{ Scale } & \multicolumn{2}{|c|}{$\begin{array}{l}\text { Younger } \\
\text { than } \\
31 \text { years }\end{array}$} & \multicolumn{2}{|c|}{$\begin{array}{c}\text { From } \\
31 \text { to } 45 \\
\text { years }\end{array}$} & \multicolumn{2}{|c|}{$\begin{array}{l}\text { From } \\
46 \text { to } 60 \\
\text { years }\end{array}$} & \multicolumn{2}{|c|}{$\begin{array}{c}\text { Older than } \\
60 \text { years }\end{array}$} & \multicolumn{2}{|c|}{ ANOVA } \\
\hline & M & DE & M & DE & M & DE & M & DE & $\mathbf{F}$ & Post hoc \\
\hline BELIEFS & 2.10 & .32 & 2.10 & .38 & 2.17 & .34 & 2.18 & .37 & 1.415 & \\
\hline $\begin{array}{l}\text { Cannot trust } \\
\text { the State and } \\
\text { justify } \\
\text { disobeying the } \\
\text { law }\end{array}$ & 1.82 & .33 & 1.84 & .36 & 1.87 & .30 & 1.95 & .36 & 2.436 & \\
\hline $\begin{array}{l}\text { Justify } \\
\text { deceiving the } \\
\text { State and the } \\
\text { use of violence }\end{array}$ & 2.48 & .42 & 2.47 & .47 & 2.57 & .51 & 2.51 & .48 & .877 & \\
\hline VALUES & 3.32 & .37 & 3.52 & .36 & 3.48 & .41 & 3.52 & .35 & $4.140 * \star$ & $1<2,4$ \\
\hline $\begin{array}{l}\text { Altruism / } \\
\text { Prosociality }\end{array}$ & 3.64 & .39 & 3.83 & .26 & 3.73 & .37 & 3.73 & .33 & $3.959 * *$ & $1<2$ \\
\hline $\begin{array}{l}\text { Respect for } \\
\text { differences }\end{array}$ & 2.92 & .54 & 3.12 & .63 & 3.16 & .62 & 3.26 & .52 & $4.030 * \star$ & $1<4$ \\
\hline KNOWLEDGE & 11.17 & 2.51 & 11.84 & 2.69 & 12.10 & 2.82 & 11.48 & 2.82 & 1.988 & \\
\hline $\begin{array}{l}\text { CONTEXT } \\
\text { PERCEPTION }\end{array}$ & 2.30 & .30 & 2.14 & .35 & 2.12 & .34 & 2.00 & .30 & $8.860 * * *$ & $1>2,3,4$ \\
\hline
\end{tabular}


Table 6. Continuation...

\begin{tabular}{|c|c|c|c|c|c|c|c|c|c|c|}
\hline \multirow[t]{2}{*}{ Scale } & \multicolumn{2}{|c|}{$\begin{array}{l}\text { Younger } \\
\text { than } \\
31 \text { years }\end{array}$} & \multicolumn{2}{|c|}{$\begin{array}{c}\text { From } \\
31 \text { to } 45 \\
\text { years }\end{array}$} & \multicolumn{2}{|c|}{$\begin{array}{l}\text { From } \\
46 \text { to } 60 \\
\text { years }\end{array}$} & \multicolumn{2}{|c|}{$\begin{array}{c}\text { Older than } \\
60 \text { years }\end{array}$} & \multicolumn{2}{|c|}{ ANOVA } \\
\hline & M & DE & M & DE & $\mathbf{M}$ & DE & M & DE & $\mathbf{F}$ & Post hoc \\
\hline $\begin{array}{l}\text { Violence and } \\
\text { disrespect for } \\
\text { rules and } \\
\text { neighbors }\end{array}$ & 1.84 & .36 & 1.66 & .37 & 1.63 & .38 & 1.47 & .32 & $\begin{array}{c}12.275^{* *} \\
*\end{array}$ & $1>2,3>4$ \\
\hline $\begin{array}{l}\text { Mistrust in the } \\
\text { State }\end{array}$ & 2.73 & .46 & 2.60 & .52 & 2.57 & .54 & 2.43 & .46 & $4.014^{\star \star}$ & $1>4$ \\
\hline $\begin{array}{l}\text { Insecurity and } \\
\text { mistrust in the } \\
\text { sector }\end{array}$ & 2.28 & .47 & 2.29 & .46 & 2.31 & .48 & 2.33 & .49 & .204 & \\
\hline
\end{tabular}

Source: Own development.

When comparing the differences according to the education level of the participants, statistically significant differences were found in the general scales of beliefs, knowledge and perception of context (Table 7). The data shows that negative beliefs about legality are inversely proportional to schooling. Specifically, the less educated farmers are more inclined to believe that the State cannot be trusted and to justify more disobeying the law in certain circumstances. However, considering that the general scores were superficial, it cannot be established that it is a prevailing belief in the population. Knowledge of the law is directly proportional to the level of schooling, and the perception of the context is more negative in those who have more education, without being high scores either.

Table 7. Average, standard deviations and Anova of a factor for scales and factors of legality perception by educational level

\begin{tabular}{|c|c|c|c|c|c|c|c|c|}
\hline \multirow[t]{2}{*}{ Scale } & \multicolumn{2}{|c|}{$\begin{array}{l}\text { No studies or } \\
\text { incomplete } \\
\text { Elementary } \\
\text { Education }\end{array}$} & \multicolumn{2}{|c|}{$\begin{array}{c}\text { Elementary } \\
\text { education or } \\
\text { Middle } \\
\text { School }\end{array}$} & \multicolumn{2}{|c|}{$\begin{array}{c}\text { High School } \\
\text { or } \\
\text { University } \\
\text { Studies }\end{array}$} & \multicolumn{2}{|c|}{ ANOVA } \\
\hline & M & DE & $\mathbf{M}$ & DE & $\mathbf{M}$ & DE & $\mathbf{F}$ & $\begin{array}{l}\text { Post } \\
\text { hoc }\end{array}$ \\
\hline BELIEFS & 2.21 & .33 & 2.14 & .36 & 2.06 & .35 & $5.547 * \star$ & $1>3$ \\
\hline $\begin{array}{l}\text { Cannot trust the State and } \\
\text { justify disobeying the law }\end{array}$ & 1.97 & .32 & 1.87 & .33 & 1.74 & .33 & $14.177^{* \star \star}$ & $1>2>3$ \\
\hline $\begin{array}{l}\text { Justify deceiving the State } \\
\text { and the use of violence }\end{array}$ & 2.54 & .45 & 2.54 & .50 & 2.47 & .51 & .610 & \\
\hline VALUES & 3.48 & .39 & 3.45 & .41 & 3.49 & .34 & .272 & \\
\hline Altruism / Prosociality & 3.74 & .35 & 3.73 & .38 & 3.75 & .29 & .092 & \\
\hline Respect for differences & 3.15 & .62 & 3.10 & .61 & 3.16 & .55 & .332 & \\
\hline Knowledge & 11.20 & 2.65 & 11.89 & 2.80 & 12.36 & 2.71 & $5.496 * *$ & $1<3$ \\
\hline CONTEXT PERCEPTION & 2.04 & .33 & 2.13 & .32 & 2.23 & .35 & $8.947 * \star \star$ & $1<3$ \\
\hline $\begin{array}{l}\text { Violence and disrespect } \\
\text { for rules and neighbors }\end{array}$ & 1.54 & .34 & 1.64 & .37 & 1.75 & .40 & 8.901 ** & $1<3$ \\
\hline Mistrust in the State & 2.49 & .51 & 2.56 & .52 & 2.68 & .50 & $3.622^{*}$ & $1<3$ \\
\hline $\begin{array}{l}\text { Insecurity and mistrust in } \\
\text { the sector }\end{array}$ & 2.35 & .47 & 2.29 & .48 & 2.27 & .47 & 1.017 & \\
\hline
\end{tabular}

Source: Own development.

The scale of values did not present significant differences depending on the education level of the rural population. In general, in the rural community of the San Nicolas Valley, there 
is no negative attitude concerning legality or a negative perception of its context in terms of law enforcement. Apparently, in this population, values and beliefs still operate and allow them to develop a behavior appropriate to the law.

\section{Discussion}

The participating farmers present compliance with the law, even when the State or the authority representation it is not reliable.

Although hypothetically, under certain circumstances breaking the law would bring them some benefit, they still maintain the conviction that nothing justifies deceiving the State or using violence. In turn, the values and the positive perception of the context in the majority of the population promote a favorable environment for the materialization of legality in the territory. This factor coincides with the study of the culture of legality and social inequality by Morán (2014) where social classes with lower economic incomes have consented to the infraction of the laws, despite having a higher perception of injustice in their applicability. It is worth highlighting in the results the proportionality between the level of studies and confidence in the State: the lower the educational level, the less confidence in the State and the more considerable justification for the violation of the law in certain circumstances, which is positively related to the results of the Perception Survey on Safety, Victimization and Coexistence in Medellin (2015), in addition going with the cultural identity shared by the sample population and the subjects of the mentioned study.

In spite of previous research, this study found significant differences in the variable values, underlying moral behavior, according to gender: Women obtained higher scores in altruism and prosociality. This finding is compatible with Alvarado Mendoza (2015) studies, when it refers that women emphasize legality according to the community, in discrepancy with men.

An issue to be resolved in future research may be measuring differences in terms of legality not only based on gender, but also between different cultures, ethnic groups and the justice system, especially in minority and invisible populations.

The results are compatible, when compared with Alvarado Mendoza (2015) findings regarding the age variable, even when the conditions are opposite (rural vs. urban). The plausible explanation lies in the evolutionary moment: young people are characterized by their critical stance to the reality that surrounds them, authority figures are no longer idealized and instead, they are harshly judged for consistency in their saying and acting. In contrast to Alvarado Mendoza (2015) conclusions, it is highlighted in this work that the attitudes of young people concerning legality are guided more by knowledge than by beliefs.

One of the original contributions of this research and that merits further inquiries is the finding of generational differences in the rural population regarding the perception of legality, where those under 31 years of age have less altruism, are less oriented by values, have greater mistrust and tend to respect differences less.

In this research, farmers older than 46 years and with less schooling have more negative beliefs regarding legality, low trust in the State and justify disobeying the law in certain circumstances, an aspect that coincides with the conclusions of Tyler et al. (2012), concerning the facilitating attitudes of authoritarianism and the potential use of violence, when state institutions are not effective. Similarly, this correlates with Black's (1983) assertion that normative attitudes predict disposition to violence. An increase in the perception of illegality in the context could make the action of justice and the naturalization of violence impossible (Moriconi Bezerra, 2015).

\section{Conclusions}

The entirety of the results in terms of beliefs, values, knowledge, and perception of the context, allows to conclude that there is a favorable perception of legality in the population sample of the San Nicolas Valley, with a behavior that is appropriate to the law. As long as the favorable circumstances are maintained, and there is no perception of violence or injustice, it can be affirmed that a culture of legality will be maintained among the peasants of the 
territory. According to theorists, everything seems to indicate that a positive perception of legality favors the maintenance of a culture of legality (Godson, 2000). However, given the rapid changes that this subregion is undergoing, it is not possible to ensure that such favorability will persist over time. The personal and community safeguard that these residents show in their relationship with legality is not enough; instead, political actions by the Colombian State are necessary to protect the peasants, their trades and their lands.

One aspect must be highlighted, the presence of fewer values and a negative perception of legality in the context of people under the age of 31 years-old. This issue could lead to unfavorable attitudes to legality and a potential resurgence of conflicts. In contrast and in the face of this eventuality, women, as they turn out to be more altruistic and prosocial than men, can serve as mediators in the face of emerging conflicts and opposition to violence. Apparently, it is not the knowledge of the law or the level of education, the protective factors against illegality and the distribution of violence. However, the altruism and prosociality are the best and most effective preservers of the population in the face of the destructive power of violent actions.

\section{References}

Alvarado Mendoza, A. (2015). Nociones de justicia, legalidad y legitimidad de las normas entre jóvenes de cinco países de América Latina. Revista Sociedade e Estado, 30(1), 75-97. http://dx.doi.org/10.1590/S0102-69922015000100006.

Black, D. (1983). Crime as social control. American Sociological Review, 48(1), 34-45.

Corpovisionarios (2015). Retos y oportunidades de la cultura ciudadana en Medellín. Medellín: Alcaldía de Medellín - Corpovisionarios.

Cortés Guardado, M. A. (2006). Cultura de la legalidad en México: creencias sobre la justicia, la ley las Instituciones. Acta republicana. Política y Sociedad, 5(5), 41-51.

Duque, L. F. (2013). Cultura de la ilegalidad en Medellín y su asociación con diversas formas de violencia. Revista Facultad Nacional de Salud Pública, 31(2), 209-215.

García, C. I. (2007). Conflicto, discursos y reconfiguración regional. El oriente antioqueño: de la Violencia de los cincuenta al Laboratorio de Paz. Controversia, 189, 130-145.

Gobernación de Antioquia. (2014). Anuario estadístico de Antioquia. Medellín: Departamento Administrativo de Planeación. Retrieved in 2015, May 28, from http://www.antioquia.gov.co/images/pdf/anuario2014/Ejecutar.html

Godson, R. (2000). Guide to developing a culture of lawfulness. Trends in Organized Crime, 5, 91-102. http://dx.doi.org/10.1007/s12117-000-1038-3

Hair, J. F., Anderson, R. E., Tatham, R. L., \& Black, C. (1999). Análisis multivariante. 5th ed. New Jersey: Pearson, Prentice-Hall.

Mathiesen, M. E., Mora, O., \& Castro, M. (1998). Valores de los estudiantes de la Universidad de Concepción (Chile). Aplicación de la escala de comportamientos morales controvertidos. Revista Latinoamericana de Psicología, 30(1), 121-136.

Medellín. Secretaría de Seguridad, Alcaldía de Medellín. Centro de Análisis Político. Universidad EAFIT. (2015). Encuesta de percepción de seguridad, victimización y convivencia en Medellín. Medellín: Secretaría de Seguridad, Alcaldía de Medellín. Retrieved in 2015, June 3, from https://www.medellin.gov.co/irj/go/km/docs/pccdesign/SubportaldelCiudadano_2/PlandeDesarroll o_0_1/Noticias/Shared\%20Content/Documentos/2015/Encuesta\%20de\%20Percepci\%C3\%B3n\%20y \%20Victimizaci\%C3\%B3n.pdf

Montoya, A., \& Pizzolitto, G. (2015). Inseguridad, impunidad y corrupción. In M. García Sánchez, J. D. Montalvo, \& M. A. Seligson (Eds.), Cultura política de la democracia en Colombia, 2015. Actitudes democráticas en zonas de consolidación territorial. Bogotá: Universidad de los Andes.

Morán, M. L. (2014). Cultura de la legalidad y desigualdad social. Consideraciones sobre el caso español. In I. Wences, R. Conde \& A. Bonilla (Ed.), Cultura de la legalidad en Iberoamérica: desafíos y experiencias. San José de Costa Rica: FLACSO/Perspectiva Digital.

Moriconi Bezerra, M. (2015). (I)legalidad y desmaterialización de la justicia: consideraciones preliminares sobre su efecto en la estabilidad psíquica del ciudadano. Revista Mexicana de Análisis Político y Administración Pública, 4(1), 9-28. 
Piedrahita Yepes, J. (Coord.). (2013). De qué vivirán los pobladores rurales. Foro Subregional del Oriente Antioqueño. Memorias del Foro Subregional del Oriente Antioqueño. Medellín: Gobernación de Antioquia.

Plan Estratégico del Oriente Antioqueño - PLANEO. (2009). Proyecto Plan Estratégico para un Pacto Social por el Desarrollo del Oriente Antioqueño. Medellín: PLANEO. Retrieved in 2015, May 28, from http://www.ervet.it/ervet/wp-content/uploads/downloads/2013/11/LibroPLANEO.pdf

Programa de las Naciones Unidas para el Desarrollo - PNUD. (2010). Oriente antioqueño: análisis de la conflictividad, 2010. Retrieved in 2015, May 29, from

https://info.undp.org/docs/pdc/Documents/COL/00058220_Analisis\%20conflictividad\%200riente\% 20Antioque\%C3\%B10.pdf

Restrepo Ramírez, N. E. (2015). Provincia del Oriente Antioqueño. Territorio en construcción. Medellín: Corporación Conciudadanía.

Salazar Ugarte, P. (2006). Democracia y (cultura de la) legalidad. México: Instituto Federal Electoral.

Sierra, D. (2015). Contexto de la ruralidad en Antioquia. In Caja de Compensación Familiar de Antioquia - COMFAMA. Cuadernos de Pensamiento Social. Agenda rural para el campo antioqueño (No. 33, pp. 612). Medellín: COMFAMA. Retrieved in 2015, June 6, from https://www.comfama.com/contenidos/bdd/47488/cuaderno33.pdf

Tyler, T. R., Jackson, J., Huq, A., \& Bradford, B. (2012). Going outside the law: the role of the state in shaping attitudes to private acts of violence (Working Paper, No. 372). Chicago: University of Chicago, Public Law \& Legal Theory.

Wences, I., Conde, R., \& Bonilla, A. (Eds.) (2014). Cultura de la legalidad en Iberoamérica: desafíos y experiencias. San José: FLACSO.

Submetido: $2 /$ Nov./2018

Aceito: 15/Mar./2020

Clasificación JEL: I31, K42, Z13. 